\title{
Re-Examining the Nexus between Exchange and Interest Rates in Nigeria
}

\author{
David Mautin Oke ${ }^{1}$, Koye Gerry Bokana ${ }^{1}$, Olatunji Abdul Shobande ${ }^{2}$ \\ ${ }^{1}$ College of Law and Management Studies, University of KwaZulu-Natal, South Africa \\ ${ }^{2}$ Faculty of Social Sciences, University of Lagos, Nigeria \\ okdam76@yahoo.com, OkeD@ukzn.ac.za
}

\begin{abstract}
Nigeria has experienced somersault of foreign exchange policies by the Central Bank. One policy concern in recent times is to have an appropriate target of the exchange and interest rates. Therefore, this paper seeks to provide a foundation for the targeting of an appropriate exchange and interest rates for the country. Using the Johansen Cointegration and Vector Error Correction Mechanism approaches, it specifically examines the relationships among Nigeria's weak exchange rate, its local rate of interest and world interest rate. Contrary to many studies, a control measure involving inclusion of inflation, money supply and national output in the model is done. The analysis showed an equilibrium association between exchange rate and interest rate-cum-other variables and steady rectification of deviance from long-run stability over a sequence of incomplete short-run modifications. Increase in domestic and world interest rate, inflation, money supply and GDPat equilibrium would strengthen the exchange rate. Besides, further findings showed some bidirectional causal associations among the variables. By long-run implication, the targeting of an appropriate exchange rate in Nigeria requires a tightened monetary policy that is not inflation and growth biased. However, increase in world interest rate, money supply and inflation rate must be moderate in order not to worsen the exchange rate as suggested by the short-run result.
\end{abstract}

Keywords: Interest rate, Exchange rate, Money supply, Inflation, GDP, Nigeria

\section{Introduction}

In the midst of another recession in Nigeria which began in 2016 after 25 years is a worsen exchange rate and a low return on investment, that is, interest rate, given the high level of inflation. Historically, Nigeria's exchange rate began to crash in1986 when the Structural Adjustment Program (SAP) was introduced. Thirty one years after, the exchange rate did not improve. It has rather gone bad with a US dollar exchanged at about NGN500 in the parallel market as at fourth quarter of 2016 and NGN380 in the second quarter of 2017. There are indications that if the governments of the country are not serious in handling the economic matters of the country, the recession may persist for more than three years and exchange rate might to continue to depreciate with low interest rate. Although there are also forecasts that the country would grow by 2.2 percent in 2017 since the oil market has gradually recovered and there is relative peace in the Niger Delta. The recession was largely due to the crash in the international oil market in 2015 and heavy drop in oil production in the country. The unfortunate scenario is that Nigerian economy remains fragile with its growth being largely financed by oil revenue (see Babatunde, 2015, Olagbaju \& Akinbobola, 2016).There remains theoretical concerns as well as constraints in the choice of exchange rate regime in both developed and developing countries. This is because the choice of exchange rate regime as well as theoretical model of exchange rate ought to consider the link with financial discipline, inflation and economic development. It implies that commitment to an exchange rate policy should be compatible with the main macroeconomic equilibrate; otherwise it will not be sustainable (see Dordunoo \& Njinkeu, 1996; Bohl, Michaelis \& Siklos, 2016).

Exchange rate policy has a long history in Nigeria. Between 1959 and 1967, Nigeria implemented fixed parity exclusively using the British pound and this was abrogated in 1972. The aftereffects of the devaluation of pound in 1967 and the onset of a powerful US dollar led to the insertion of US dollar in the exchange rate parity. In 1973, the US dollar was devaluated and Nigeria returned to fixed parity with the pound. As a way of reducing the counter bounce effect of devaluation of the individual currency parity, both British pound and US dollar were considered. In 1978, the central bank reverted to import weighted basket of currency method which was considered due to the tie of seven currencies: US dollar, British pounds, Japanese Yen, French Franc, German Mark, Swiss franc and Dutch guilder. In sum, between 1980 and 2016, the fixed and flexible exchange rate systems were used interchangeably. This paper seeks to investigate the nexus between exchange rate and interest rate in Nigeria. Specifically, it tests the long run relationship among exchange rate, 
world interest-cum- domestic-interest rate, output level, inflation, and money supply. The relevance of this study is that it would provide a recent and additional empiric on the issue of exchange rate crisis in Nigeria, thereby giving a timely foundation for targeting both the exchange and interest rates. This is pertinent because the Central Bank of Nigeria in recent times seems not to have an enduring solution to the exchange rate crises. The study is therefore a timely one. The remaining part of this paper is broken into five segments. Segment 2 provides a synopsis of the literature review. Following is the theoretical framework and methodological approaches in part 3. Results of the study are presented and discussed in part 4 while section 5 contains the conclusion including policy suggestions.

\section{Literature Review}

There are at least three theoretical approaches to explaining the existing connection between exchange rate and interest rate. The first is the Purchasing Power Parity hypothesis that suggested that exchange rate among countries of the world should be relative to the expected inflation (Yahya, Bany-Ariffin \& Abdul Hadi, 2011, and Yaaba, Bawa \& Idrisa, 2012). The second is the Covered and Uncovered Interest rate parity theory (CIRP and UIRP). The CIRP model earlier suggested equal rate of return between domestic and foreign financial investment. On the other hand, the uncovered interest rate parity model presents a conflicting line of argument suggesting that there is no reason for equating the world interest rate since the level of productivity differs. The hypothesis argues that a rise in the domestic or local rate of return over the world rate of return has been seen as appreciation of currency of the domestic economy over the foreign economy which may enhance balance of payments and competitive advantage. The third theoretical literature is the monetary policy approach to modeling the exchange rate in terms of relative price with the demand and supply paradigm (Vagiatzoglou, Christodolous, Pazarkis \& Donglas, 2006).

Exchange and interest rates nexus are issues in monetary policy. Several studies have examined the impact of monetary policies on exchange rate. For instance, according to Mundell (1973a, 1973b), monetary policy and exchange rate are the paramount reasons behind uncertainty and fluctuation in small economies. The study by Chete (1995) attempted to evaluate Nigerian experience with exchange rate depreciation. His study involved the process of generating elasticities. The author claimed that trade flow and reserve models are responsible for the fluctuation in exchange rate in Nigeria during the period reviewed. Similarly, Ndung's (1999) paper decomposed the real exchange rate into cyclical and permanent components. The author's causality test between several measures of monetary policy and real exchange rate shows that there are rebounced effects of the reaction of monetary policy on exchange rate fluctuation in the short run through the money market. Another study on exchange rates and interest rates nexus that is popular in the literature is the work of Sanchez (2005). The work, on small open economies, integrates the role of exchange rate passthrough into domestic prices as well as separates between cases of contractionary and expansionary depreciations. On the condition of an adverse risk premium shock, it was found out that the connection between exchange rates and interest rates is direct or positive for contractionary depreciations and indirect or negative for expansionary ones.

This study is consistent with the studies by Eichengreen (2005), Calvo \& Reinhart (2001 and 2002), and Calvo (2001) who attempted to investigate the association between interest rate and exchange rate targeting. This group of scholars insisted that credibility difficulties, non-stationarities, liability dollarization and a high exchange rate pass-through are crucial issues for validating this relationship. For instance, Calvo \& Reinhart (2002) and Eichengreen (2005) found out that existence of exchange rate rigidities that inform watching of reactions of interest rate to offset fluctuations in foreign exchange markets is a major concern for developing economies. Also some studies have argued that negative impact of fragile real exchange rate has severe implication on aggregate demand (see Mohanty \& Klau (2005), Cavoli \& Rajan (2005) and Eichengreen (2005)). The findings of these studies are consistent with the opinion of Calvo (2001) that fragile exchange rates may result to pervasive bankruptcies, which we know often cause output loss.

A study by Chow \& Kim (2004) suggest that Indonesia, Korea, Philippines and Thailand do not adopt interest rate policy more vigorously to even out exchange rates in a post-financial crisis era hence their domestic currencies show more sensitivity to competitors' exchange rates in post-crisis period. Besides, their findings confirmed that stability of interest rate has not emanated from high plasticity of exchange rate in the 
countries. In Namibia, Wilson \& Sheefeni (2014) examined whether there is association between exchange rate and interest rate. They employed a multi-variate cointegration approach using quarterly data over the period, 1993 to 2012. A no cointegration relationship was established. The study by Simone \& Razzak (1999) projected that a rise in interest rate discrepancy leads to exchange rate appreciation. In addendum, Ezirim, Edith \& Muoghalu (2012) examined the mutual association between the manner, which exchange and interest rates behave in Nigeria. Employing autoregressive distributed lag approach; exchange rate and inflation spiral were associated in the short and long run. The study therefore showed that in targeting either inflation or exchange rate, mutual policies on both variables are ideal.

Also more studies that have examined whether there are connections between real interest rates and the real exchange rate, such as Mark (2009), Alquist \& Chinn (2008), and Engel \& West (2006), have supported the existence of empirical connection. However, the studies by Clarida and Waldman (2008), Andersen, Tim, Francis \&Clara (2007) and Faust, Rogers, Wang \& Wright (2007) have shown that there is a strong connection between response of real exchange rate to news that change the expected real interest differential. In literature, many studies have been carried out to investigate the relationship between interest rate and exchange rate but there seems to be no consensus regarding the generalization of the relationships as well as which studies are mostly acceptable. Most of the works on this relationship have submitted a call for enquiry to validate the existing findings.

\section{Methodology}

Among the objectives of monetary policy are to ensure exchange rate stability and regulate the fluctuation in price level. Therefore, the theoretical foundation of this study is based on the interest rate parity hypothesis that suggests a positive connection between interest rate and exchange rate. The implication of this is that for a country to achieve a stable exchange rate, its interest should be close to foreign interest rate. The hypothesis maintains that any country that wants to depreciate its exchange rate by a value has to reduce its interest rate by the right amount (see Blanchard, 2009). The justification for the consideration of this hypothesis is based on its monetary framework, which is anchored on the premises that interest rate targeting has to be concerned with the exchange rate, and vice-versa. Following the argument of the importance of interest rate in monetary policy transmission on the exchange rate in developed and developing countries, this study's model follows closely the work of Eichengreen (2005), Calvo \&Reinhart (2001 and 2002), and Calvo (2001).

Functionally and mathematically, it is stated thus:

$\mathrm{EXCH}_{\mathrm{t}}=\propto+\varphi_{1}\left(\mathrm{DINT}_{\mathrm{t}}\right)+\varphi_{2}\left(\right.$ MOS $\left._{t}\right)+\varphi_{3}\left(\right.$ DOUTP $\left._{t}\right)+\varphi_{4}\left(I N F_{t}\right)+\varphi_{5}\left(W_{I N T_{t}}\right)+\mu_{\mathrm{t}}(1)$

To control for the connection between interest rate and exchange rate, some exogenous factors (which are control variables) and stochastic term are incorporated in the model in equation (1). By definition, EXCH $=$ Exchange rate and DINT $=$ Domestic interest rate (minimum rediscount rate/ monetary policy rate). DOUTP $=$ Domestic output level, Money supply (MOS), Inflation rate (INF), and World interest rate (WINT) = Control variables, $\propto=$ Constant, $\varphi_{1 \ldots . . .} \varphi_{5}=$ Slopes, $\mu=$ Stochastic term and $\mathrm{t}=$ Time.

A Vector Error Correction (VEC) model is employed for short-run changes of equation (1). This is a constrained Vector Autoregression (VAR), that is, co-integration constraints are structured into the specification, so that it is structured for use with series that are not stationary but are co-integrated.

Assuming a system of two variables with no lagged differences terms but has one co-integrating equation such as:

$y_{1 t}=\varphi_{1} y_{2 t}+\mu_{t}$

$y_{2 t}=\varphi_{2} y_{1 t}+\mu_{t}$

and the VEC specifications are

$\Delta y_{1 t}=\gamma_{1}\left(y_{2 t-1}-\varphi_{1} y_{1 t-1)}+v_{1 t}\right.$

$\Delta y_{2 t}=\gamma_{2(} y_{2 t-1}-\varphi_{1} y_{1 t-1)}+v_{2 t}$

In the VEC equations, $v_{1 t}$ and $v_{2 t}$ are the error correction terms. At equilibrium, these terms are zero. Nonetheless, assuming in previous period, there are digressions of $\mathrm{y}_{1}$ and $\mathrm{y}_{2}$ from the long run equilibrium, $v_{1 t}$ and $v_{2 t}$ are nonzero; each variable adjust to incompletely restore the equilibrium association. Adjustment speeds are measured by $\gamma_{1}$ and $\gamma_{2}$ coefficients. A nonzero $\mathrm{y}_{1 \mathrm{t}}$ at $\mathrm{y}_{2 \mathrm{t}}$ are obtained, but the co-integrating equation 
will have intercept of zero. Notwithstanding a common lagged difference, there is no lagged difference on the right hand side (Attanasio, Blundell \& Preston, 2000).

Assuming that $\Delta \mathrm{y}_{1 \mathrm{t}}$ and $\Delta \mathrm{y}_{2 \mathrm{t}}$ as endogenous variables have co-integrating equations with an intercept but no trend, the form of the VEC specifications are:

$\Delta y_{1 t}=\gamma_{1}\left(y_{2 t-1}-\mu-\varphi_{1} y_{1 t-1)}+v_{1 t}\right.$

$\Delta y_{2 t}=\gamma_{2}\left(y_{2 t-1}-\mu-\varphi_{1} y_{1 t-1}\right)+v_{2 t}$

Additional, assuming the series have linear trend and the co-integrating equations have a constant, the VEC specification has the form:

$\Delta y_{1 t}=\delta_{1}+\partial_{1}\left(y_{2 t-1}-\mu-\varphi_{1} y_{1 t-1}\right)+v_{1 t}$

$\Delta y_{2 t}=\delta_{2}+\partial_{2}\left(y_{2 t-1}-\mu-\varphi_{1} y_{1 t-1}\right)+v_{2 t}$

All the data were collected from Volume 26 of the 2015 edition of the Statistical Bulletin of the Central Bank of Nigeria and 2015 edition of the World Development Indicator. The period of study covers from 1980: Q1 to 2015:Q4. The variables are all in growth rates.

\section{Results}

The descriptive result in Table 1 presents the descriptive analysis of the time series properties of the model's variables. The table shows that the average quarterly growth values of exchange rate, money supply, inflation rate, domestic interest rate, domestic output level and world interest rate over the reference period stood at $4.3 \%, 10.0 \%, 6.9 \%, 5.3 \%, 8.8 \%$ and $10.0 \%$, respectively. The standard deviation of exchange rate, money supply, inflation rate, domestic interest rate, domestic output level and world interest rate from their respective long term mean values in every quarter stood at $2.1 \%, 3.9 \%, 1.5 \%, 2.7 \%, 2.2 \%$, and $2.0 \%$. Contrary to expectation, world interest rate deviates more from its mean than other variables.

Table 1: Pre-test A: Descriptive Statistics

\begin{tabular}{lllllll}
\hline & EXCH & DINT & MOS & DOUTP & INF & WINT \\
\hline Mean & 4.345931 & 5.266961 & 9.998805 & 8.819187 & 6.863963 & 9.998131 \\
Median & 5.010436 & 6.642430 & 8.774406 & 8.765423 & 4.801804 & 3.032644 \\
Maximum & 7.442822 & 5.115461 & 6.891931 & 6.854027 & 7.372543 & 7.637370 \\
Minimum & 0.421137 & 5.361608 & 6.635649 & 2.386326 & 3.171294 & 6.437167 \\
Std. Dev. & 2.053652 & 2.740983 & 3.860207 & 2.167731 & 1.461730 & 2.015497 \\
Skewness & 0.113326 & 3.308035 & 5.659981 & 6.172530 & 0.238926 & 0.003623 \\
Kurtosis & 1.705369 & 3.055744 & 5.664367 & 3.055615 & 4.399502 & 2.433351 \\
Jarque-Bera & 5.758138 & 6.275497 & 15.04139 & 10.369767 & 7.289826 & 12.070480 \\
Probability & 0.046187 & 0.045481 & 0.000542 & 0.015466 & 0.026124 & 0.00529 \\
Observations & 144 & 144 & 144 & 144 & 144 & 144 \\
\hline
\end{tabular}

Source: Computed by the Authors

The correlation matrix in Table 2 clearly shows that there is no problem of multicollinearity among the explanatory variables. Therefore, econometric problems associated with multicollinearity are not issues of concern.

Table 2: Pre-test B: Correlation Matrix

\begin{tabular}{lllllll}
\hline & EXCH & DINT & MOS & DOUTP & INF & WINT \\
\hline EXCH & 1 & 0.50803 & 0.65254 & 0.89136 & 0.450102 & 0.6373 \\
DINT & & 1 & 0.21851 & 0.12089 & 0.26790 & 0.37516 \\
MOS & & & 1 & 0.24935 & 0.40861 & 0.39777 \\
DOUTP & & & & 1 & 0.25685 & 0.43871 \\
INF & & & & & 1 & 0.24006 \\
WINT & & & & & & 1 \\
\hline
\end{tabular}

Source: Computed by the Authors 
As shown in Tables 3 and 4, the Ng-Perron Modified Unit Root test and the Dickey Fuller Generalized Least Squares results indicate that the variables are first difference stationary. The Schwartz-Bayesian Information Criterion (SBIC) and Akaike Information Criterion (AIC) and are regularly employed to select the optimum lag length in distributed-lag models that are of single-variable. This study includes the Hannan-Quinm Information Criteria (HQ) among others. The optimal lag length by each criterion as revealed in Table 5 is indicated by an asterisk. Universally, lag 1 was agreed to by all the criteria. Further, the Trace statistics and Maximum Eigenvalues in Table 6 of the Johansen's co-integration approach shows the long run associations among the variables. The table value of $5 \%$ significance level is employed. The null hypothesis of no cointegration is rejected. Precisely, there are two co-integrating equations in the model. This is contrary to the findings of Wilson and Sheefeni (2014).

Table 3: Pre-Test C: Ng Perron Modified Unit Root Test Results

\begin{tabular}{lllll}
\hline VARIABLE & Mza & MZt & MSB & MPT \\
\hline$\Delta$ EXCH & $-35.9951^{* *}$ & -5.02952 & 0.52212 & 0.73996 \\
$1 \%$ & $(-13.8000)$ & $(23.5800)$ & $(0.17400)$ & $(1.78000)$ \\
$5 \%$ & $(-8.1000)$ & $(-1.98000)$ & $(0.23300)$ & $(3.17000)$ \\
$\Delta$ DINT & $-58.3992^{* *}$ & -6.75022 & 0.06407 & 0.67560 \\
$1 \%$ & $(-13.8000)$ & $(23.5800)$ & $(0.17400)$ & $(1.78000)$ \\
$5 \%$ & $(-8.1000)$ & $(-1.98000)$ & $(0.23300)$ & $(3.17000)$ \\
$\Delta$ MOS & $-85.8266^{* *}$ & -4.71294 & 0.05563 & 6.45151 \\
$1 \%$ & $(-13.8000)$ & $(23.5800)$ & $(0.17400)$ & $(1.78000)$ \\
$5 \%$ & $(-8.1000)$ & $(-1.98000)$ & $(0.23300)$ & $(3.17000)$ \\
$\Delta$ DOUTP & $-64.9183^{* *}$ & -5.20820 & 0.61399 & 0.71756 \\
$1 \%$ & $(-13.8000)$ & $(23.5800)$ & $(0.17400)$ & $(1.78000)$ \\
$5 \%$ & $(-8.1000)$ & $(-1.98000)$ & $(0.23300)$ & $(3.17000)$ \\
$\Delta$ INF & $-26.2037^{* *}$ & -5.12957 & 0.51406 & 4.20048 \\
$1 \%$ & $(-13.8000)$ & $(23.5800)$ & $(0.17400)$ & $(1.78000)$ \\
$5 \%$ & $(-8.1000)$ & $(-1.98000)$ & $(0.23300)$ & $(3.17000)$ \\
$\Delta$ WINT & $-41.9970^{* *}$ & -6.95711 & 0.22367 & 4.09150 \\
$1 \%$ & $(-13.8000)$ & $(23.5800)$ & $(0.17400)$ & $(1.78000)$ \\
$5 \%$ & $(-8.1000)$ & $(-1.98000)$ & $(0.23300)$ & $(3.17000)$ \\
\hline
\end{tabular}

Note: $\Delta$ symbolizes that the variables are in their first difference. The asymptotic critical values of $\mathrm{Ng}$-Perron Modified unit root tests are in their respective levels of significance. ${ }^{* *}(*)$ denotes the rejection of the null hypothesis at $1 \%(5 \%)$ significance level.

Source: Computed by the Authors using E-views

Table 4: Pre-Test D: Dickey Fuller - GLS Unit Root Test Results

\begin{tabular}{lllll}
\hline Variable & T-Statistics & $\mathbf{1 \%}$ & $\mathbf{5 \%}$ & Order of Integration \\
\hline$\Delta$ EXCH & $-36.17766^{* *}$ & -2.594946 & -1.945024 & $\mathrm{I}(1)$ \\
$\Delta$ DINT & $-5.216038^{* *}$ & -2.594946 & -1.945024 & $\mathrm{I}(1)$ \\
$\Delta$ MOS & $-6.773441^{* *}$ & -2.594946 & -1.945024 & $\mathrm{I}(1)$ \\
$\Delta$ DOUTP & $-9.82620^{* *}$ & -2.594946 & -1.945024 & $\mathrm{I}(1)$ \\
$\Delta$ INF & $-9.12950^{* *}$ & -2.594946 & -1.945024 & $\mathrm{I}(1)$ \\
$\Delta$ WINT & $-5.944243^{* *}$ & -2.594946 & -1.945024 & $\mathrm{I}(1)$ \\
\hline
\end{tabular}

Note: $\Delta$ symbolizes that the variables are in their first difference. The asymptotic critical values of Dickey Fuller GLS unit root tests are in their respective levels of significance. ${ }^{* *}\left({ }^{*}\right)$ denotes the rejection of the null hypothesis at $1 \%$ (5\%) significance level.

Source: Computed by the Authors using E-views 
Table 5: Diagnostic Test: Lag Selection Information Criterion

\begin{tabular}{|c|c|c|c|c|c|c|}
\hline Lag & $\begin{array}{l}\text { Log } \\
\text { Likehood }\end{array}$ & $\begin{array}{l}\text { LR } \\
\text { (statistics) }\end{array}$ & $\begin{array}{l}\text { Final } \\
\text { Prediction } \\
\text { Error (FPE) }\end{array}$ & $\begin{array}{l}\text { Akaike } \\
\text { Information } \\
\text { Criteria } \\
\text { (AIC) }\end{array}$ & $\begin{array}{l}\text { Schwartz } \\
\text { Information } \\
\text { Criteria (SC) }\end{array}$ & $\begin{array}{l}\text { Hannan-Quinm } \\
\text { Information Criteria } \\
\text { (HQ) }\end{array}$ \\
\hline 0 & -689.5754 & NA & 2.828195 & 18.06689 & 18.24953 & 18.13994 \\
\hline 1 & -416.5627 & $496.3866^{*}$ & $0.006015^{*}$ & $11.91072^{*}$ & $13.18916^{*}$ & 12.42208* \\
\hline 2 & -394.2009 & 37.17296 & 0.008715 & 12.26496 & 14.63920 & 13.21463 \\
\hline 3 & -364.0941 & 45.35566 & 0.010601 & 12.41803 & 15.88808 & 13.80602 \\
\hline
\end{tabular}

Note: * Indicates the lag order selected by each criterion. Each value of LR statistics is at $5 \%$

Source: Computed by the Authors

Based on the findings in table 7, an increase in domestic and global interest rates, money supply, inflation and domestic output, in the long run, makes the exchange rate to be strong because these variables reduced the exchange rate. Therefore, the effects of all the explanatory variables at equilibrium are a-theoretic except the national output. Contrary findings to our result on exchange rate and interest rate nexus are those of Eichengreen (2005), Calvo \& Reinhart (2001 and 2002), and Calvo (2001). We expect an expansionary monetary policy that reduces the interest rates, raises the money supply moderately without fueling inflation but able to significantly increase the national output or GDP to reduce the exchange rate. However, our findings have supported a contractionary or tightened monetary policy that is not inflation and economic growth biased in the long run. This is because tightened monetary policy increases interest rates, reduces money supply and inflation as well as GDP. The study by Simone and Razzak (1999) found a similar result with ours on the connection between interest rate and exchange rate. Our finding on the association between exchange rate and national output is similar with those of Mohanty \& Klau (2005), Cavoli \& Rajan (2005) and Eichengreen (2005).

Table 6: Johansen Maximum Likelihood Cointegration Test Results

\begin{tabular}{|c|c|c|c|c|c|c|c|c|}
\hline & \multicolumn{2}{|c|}{ Trace Test } & \multicolumn{2}{|c|}{$\mathrm{k}=1$} & \multicolumn{3}{|c|}{ Maximum Eigenvalues Test } & \multirow{2}{*}{$\begin{array}{l}\text { k=1 } \\
\text { Critical } \\
\text { values }\end{array}$} \\
\hline & $\mathbf{H}_{\mathbf{0}}$ & $\mathbf{H}_{\mathrm{A}}$ & ( $\lambda$ trace $)$ & $\begin{array}{l}\text { Critical } \\
\text { values }\end{array}$ & $\mathbf{H}_{\mathbf{O}}$ & $\mathbf{H}_{\mathbf{A}}$ & $(\lambda \max )$ & \\
\hline Equation & & & & $5 \%$ & & & & $5 \%$ \\
\hline None* & $r \leq 0$ & $r>0$ & 153.2955 & 95.75366 & $r=0$ & $r=1$ & 57.54554 & 40.07757 \\
\hline $\begin{array}{l}\text { At most } \\
1^{*}\end{array}$ & $r \leq 0$ & $r>0$ & 128.1264 & 69.81889 & $r=0$ & $r=1$ & 32.65968 & 31.56566 \\
\hline At most 2 & $r \leq 0$ & $r>0$ & 57.85613 & 65.89521 & $r=0$ & $r=1$ & 30.59564 & 31.0889 \\
\hline At most 3 & $r \leq 0$ & $r>0$ & 29.79707 & 39.59652 & $r=0$ & $r=1$ & 25.96812 & 27.68512 \\
\hline At most 4 & $r \leq 0$ & $r>0$ & 15.98987 & 20.98945 & $r=0$ & $r=1$ & 19.54966 & 18.57412 \\
\hline
\end{tabular}

Note $(*)$ denotes the rejection of the null hypothesis at (5\%) significance level.

Source: Computed by the Authors using E-views

Table 7: Normalised Cointegrating Coefficients (Standard Error in Parentheses): The Long Run Model

\begin{tabular}{llllcc}
\hline EXCH & DINT & MOS & DOUPT & INF & WINT \\
\hline 1.000000 & $0.58612^{* *}$ & $0.33554^{* *}$ & $0.06658^{* *}$ & $0.98932^{* *}$ & $0.65645^{*}$ \\
& $(0.02858)$ & $(0.0 .5485)$ & $(0.01666)$ & $(0.38988)$ & $(0.25787)$ \\
\hline
\end{tabular}

** $(*)$ denotes the rejection of the null hypothesis at 1\% (5\%) significance level. As usual, the cointegrating coefficients of the normalized regression are reported in an alternating manner. That is, we take positive values of the coefficients as negative values and vice versa.

Source: Computed by the Authors using E-views

In econometric investigations, a cointegrated set of time series variables must have an error-correction representation, which illustrates the short-run correction mechanism. Haven established that all the variables in the model are I (1) and cointegration exists, a VECM with equations is, therefore, estimated. Its results in Table 8 show correctly signed and significant coefficients of the error-correction term of the cointegrating vectors at $1 \%$ level. This suggests that the digression from long-run equilibrium is corrected gradually 
through a series of incomplete short-run adjustments. The results also show that in the short -run, increase in money supply, GDP, inflation, and world interest rate in exception of domestic interest rate will worsen the exchange rate.

Table 8: Vector Error Correction for Short-Run Model

\begin{tabular}{|c|c|c|c|c|c|c|}
\hline Error Correction & $\Delta(\mathrm{EXCH})$ & $\Delta$ (DINT) & $\Delta$ (MOS) & $\Delta$ (DOUPT) & $\Delta$ (INF) & $\Delta$ (WINT) \\
\hline $\operatorname{ECM}(-1)$ & $\begin{array}{r}-0.955422 \\
(0.25897) \\
{[-3.68931]}\end{array}$ & $\begin{array}{r}-0.545556 \\
(0.15985) \\
{[-3.41292]}\end{array}$ & $\begin{array}{c}-0.985941 \\
(0.25498) \\
{[-3.86673]}\end{array}$ & $\begin{array}{c}-0.789565 \\
(0.25455) \\
{[-3.10187]}\end{array}$ & $\begin{array}{c}-0.189645 \\
(0.02451) \\
{[-7.73745]}\end{array}$ & $\begin{array}{c}-0.354451 \\
(0.15451) \\
{[-2.2943]}\end{array}$ \\
\hline$\Delta(\operatorname{EXCH}(-1))$ & $\begin{array}{c}0.256585 \\
(0.02545) \\
{[10.08192]}\end{array}$ & $\begin{array}{c}-0.155485 \\
(0.05545) \\
{[-2.804057]}\end{array}$ & $\begin{array}{c}0.569925 \\
(0.08755) \\
{[6.509708]}\end{array}$ & $\begin{array}{c}0.787152 \\
(0.21855) \\
{[3.601702]}\end{array}$ & $\begin{array}{l}0.565544 \\
(0.14454) \\
{[3.912716]}\end{array}$ & $\begin{array}{c}0.595214 \\
(0.14545) \\
{[4.092224]}\end{array}$ \\
\hline$\Delta($ DINT $(-1))$ & $\begin{array}{c}4.456531 \\
(2.06555) \\
{[2.10575]}\end{array}$ & $\begin{array}{r}-0.546212 \\
(0.25465) \\
{[-2.14495]}\end{array}$ & $\begin{array}{c}3.653232 \\
(1.25654) \\
{[2.90737]}\end{array}$ & $\begin{array}{c}0.355660 \\
(0.06999) \\
{[5.081583]}\end{array}$ & $\begin{array}{c}2.544881 \\
(1.05264) \\
{[2.41761]}\end{array}$ & $\begin{array}{r}-0.894521 \\
(0.25644) \\
{[-3.48822]}\end{array}$ \\
\hline$\Delta(\operatorname{MOS}(-1))$ & $\begin{array}{c}-0.452565 \\
(0.05657) \\
{[-8.0000]}\end{array}$ & $\begin{array}{c}-0.898921 \\
(0.04989) \\
{[-18.01805]}\end{array}$ & $\begin{array}{c}-0.488781 \\
(0.02454) \\
{[-19.91773]}\end{array}$ & $\begin{array}{c}0.545411 \\
(0.04571) \\
{[11.93198]}\end{array}$ & $\begin{array}{l}0.598211 \\
(0.05898) \\
{[10.14260]}\end{array}$ & $\begin{array}{r}-0.545471 \\
(0.05455) \\
{[-9.99946]}\end{array}$ \\
\hline$\Delta$ (DOUPT $(-1))$ & $\begin{array}{c}-0.788981 \\
(0.05659) \\
{[-13.94205]}\end{array}$ & $\begin{array}{c}0.529892 \\
(0.04747) \\
{[11.16267]}\end{array}$ & $\begin{array}{r}-0.989522 \\
(0.20566) \\
{[-4.81144]}\end{array}$ & $\begin{array}{c}-0.455648 \\
(0.54565) \\
{[-2.83385]}\end{array}$ & $\begin{array}{c}-0.30556 \\
(0.05412) \\
{[-5.64597]}\end{array}$ & $\begin{array}{c}0.244389 \\
(0.08562) \\
{[2.85434]}\end{array}$ \\
\hline$\Delta(\operatorname{INF}(-1))$ & $\begin{array}{c}0.308993 \\
(0.12006) \\
{[2.57365]}\end{array}$ & $\begin{array}{c}0.042755 \\
(0.01733) \\
{[2.467109]}\end{array}$ & $\begin{array}{c}0.149178 \\
(0.01794) \\
{[8.31538]}\end{array}$ & $\begin{array}{c}-0.991005 \\
(0.32534) \\
{[-3.046059]}\end{array}$ & $\begin{array}{c}-0.369230 \\
(0.17384) \\
{[-2.12392]}\end{array}$ & $\begin{array}{c}0.088359 \\
(0.02328) \\
{[3.79536]}\end{array}$ \\
\hline$\Delta($ WINT $(-1))$ & $\begin{array}{c}-0.656354 \\
(0.05565) \\
{[-11.79432]}\end{array}$ & $\begin{array}{r}-0.088150 \\
(0.01768) \\
{[-4.98586]}\end{array}$ & $\begin{array}{c}-0.656211 \\
(0.54663) \\
{[-2.04986]}\end{array}$ & $\begin{array}{c}-0.75652 \\
(0.05742) \\
{[-13.17520]}\end{array}$ & $\begin{array}{c}0.222290 \\
(0.07735) \\
{[2.87382]}\end{array}$ & $\begin{array}{c}-0.756624 \\
(0.26987) \\
{[-2.803661]}\end{array}$ \\
\hline CONSTANT & $\begin{array}{c}-0.587124 \\
(0.11478) \\
{[-5.11521]}\end{array}$ & $\begin{array}{c}0.587232 \\
(0.05458) \\
{[10.75910]}\end{array}$ & $\begin{array}{c}-0.96682 \\
(0.05748) \\
{[-16.82011]}\end{array}$ & $\begin{array}{c}0.238764 \\
(0.03766) \\
{[6.33679]}\end{array}$ & $\begin{array}{c}-0.653346 \\
(0.20143) \\
{[-3.24358]}\end{array}$ & $\begin{array}{l}0.586571 \\
(0.05689) \\
{[10.310617]}\end{array}$ \\
\hline R-squared & 0.826568 & 0.778752 & 0.768922 & 0.795281 & 0.806958 & 0.728086 \\
\hline $\begin{array}{l}\text { Adj. R-squared } \\
\text { F-Statistic }\end{array}$ & $\begin{array}{l}0.792154 \\
29.58798\end{array}$ & $\begin{array}{c}0.766555 \\
27.85871\end{array}$ & $\begin{array}{l}0.756891 \\
26.96855\end{array}$ & $\begin{array}{l}0.791190 \\
19.11382\end{array}$ & $\begin{array}{l}0.767654 \\
21.42914\end{array}$ & $\begin{array}{l}0.715712 \\
18.59572\end{array}$ \\
\hline
\end{tabular}

Source: Computed by the Authors

Table 9 shows the result of the residual diagnostic tests for serial correlation, heteroscedasticity and joint normality test.

Table 9: Post-Examination of the Short-Run Model

\begin{tabular}{llll}
\hline Normality (P-Value) & Autocorrelation (P-Value) & Heteroscedascity(P-Value) \\
\hline Skewness & $0.014978(0.02579)$ & LM Stat. $=2.5989(0.09776)$ & Chi-Square $=1.59755(0.11655)$ \\
Kurtosis & $2.82647(0.03697)$ & & \\
Jarque-Bera & $2.56478(0.43763)$ & & \\
\hline
\end{tabular}

Source: Computed by the Authors

The coefficient and p-value of the Jarque-Bera shows that the null hypothesis cannot be rejected. Therefore, the residual is normally distributed with zero mean and constant variance. Furthermore, the hypotheses of these two plagues "that there is no serial correlation" and "that there is no heteroscedasticity" failed to be 
rejected. This means that the study is free from econometric problems of autocorrelation and heteroscedasticity,

Table 10: Pairwise Granger Causality Tests

\begin{tabular}{|c|c|c|c|}
\hline Null Hypothesis: & \multicolumn{2}{|c|}{ ObservationF-Statistic } & Prob. \\
\hline DINT does not Granger Cause EXCH & 143 & 10.6558 & 0.0401 \\
\hline EXCH does not Granger Cause DINT & 143 & 15.5452 & 0.0391 \\
\hline MOS does not Granger Cause EXCH & 143 & 19.5455 & 0.0295 \\
\hline EXCH does not Granger Cause MOS & 143 & 20.9891 & 0.0254 \\
\hline DOUTP does not Granger Cause EXCH & 143 & 8.12526 & 0.0423 \\
\hline EXCH does not Granger Cause DOUPT & 143 & 9.65961 & 0.0419 \\
\hline INF does not Granger Cause EXCH & 143 & 25.65965 & 0.0215 \\
\hline EXCH does not Granger Cause INF & 143 & 30.65961 & 0.0108 \\
\hline WINT does not Granger Cause EXCHR & 143 & 6.45656 & 0.0458 \\
\hline EXCH does not Granger Cause WINT & 143 & 14.54655 & 0.0399 \\
\hline DINT does not Granger Cause MOS & 143 & 15.59959 & 0.0383 \\
\hline DINT does not Granger Cause DOUPT & 143 & 17.96126 & 0.0314 \\
\hline MOS does not Granger Cause DOUPT & 143 & 17.13256 & 0.0345 \\
\hline INF does not Granger Cause DINT & 143 & 21.23968 & 0.0223 \\
\hline INF does not Granger Cause WINT & 143 & 20.87661 & 0.0259 \\
\hline WINT does not Granger Cause DINT & 143 & 9.765612 & 0.0404 \\
\hline
\end{tabular}

Source: Computed by the Authors

Table 10 shows the results of the Granger causality test among the variables. The null hypothesis is that there is no causality among the variables. The F-Statistic and the corresponding $p$-value as presented in the second and third columns of the table show that exchange rate, domestic and foreign or world interest rate, domestic output, money supply and inflation are all bi-directional. These results are consistent with those of Ndung (1999), Sanchez (2005), Engel and West (2006), Mark (2009), Alquist and Chinn (2008) as well as the submission of Blanchard (2009) and Ezirim et al. (2012) on the relationship between exchange rate and inflation in Nigeria.

\section{Conclusion}

In this paper, we estimated on Nigeria, the relationship between domestic and world interest rates and exchange rate with money supply, national output and inflation serving as controlled variables. The model employed is widely anchored on the interest rate parity hypothesis. The rationale is to provide further foundation for targeting the exchange and interest rates in Nigeria. The result established a long run relationship between interest rate and exchange rate, which suggests that the monetary authority should further make concerted effort to manage the monetary policy rate more effectively to avoid further exchange rate crisis in the economy. Since the study establishes that an increase in money supply at equilibrium would fortify the exchange rate, it follows that an increase in money supply in a reasonable manner that spur growth without fueling inflation excessively would be required to support the exchange rate in the long-run. Most importantly, a tightened monetary policy would help to curtail excessive inflation whenever it occurs and this would raise the value of the Naira. The positive relationship noticed between inflation and exchange rate in the short-run exposes the destabilizing tendencies of inflationary pressure in short-run. However, a moderate increase in inflation is required in the long-run. It suffices to note that exchange rate performance in Nigeria has mutual linkages with domestic and world interest rates as well as money supply, inflation and national output in the long-run. Therefore, targeting both exchange and interest rates in Nigeria as well stabilizing the country's exchange rate in the long-run requires a mutually inclusive policy in this regards. This study has pointed out the need for Nigeria to rapidly diversify its economy and become innovative so that its national output can improve the exchange rate. 


\section{References}

Alquist, R. \& Chinn, M. (2008). Conventional and Unconventional Approaches to Exchange Rate Modeling and Assessment. International Journal of Finance and Economics, 13, 2-13.

Andersen, T. G., Tim B., Francis X. D. \& Clara, V. (2007).Real-Time Price Discovery in Global Stock, Bond and Foreign Exchange Markets. Journal of International Economics, 73(2), 251-277.

Attanasio, O. P., Blundell, R. \& Preston, I. (2000). From Wage Shocks to Consumption. Mimeo, London: University College.

Blanchard, O. (2009). Macroeconomics (5th ed), New Jersey: Prentice Hall.

Babatunde, M. A. (2015). Oil Price Shocks and Exchange Rate in Nigeria. International Journal of Energy Sector Management, 9(1), 2-19.

Bohl, M. T., Michaelis, P. \& Siklos, P. L. (2016). Austerity and Recovery: Exchange Rate Regime Choice, Economic Growth and Financial Crises. Economic Modeling, 53, 195-207

Calvo, G. (2001). Capital Markets and the Exchange Rate. With Special Reference to Dollarization Debate in Latin America. Journal of Money, Credit and Banking, 33, 312-334.

Calvo, G. \& Reinhart, C. (2001). Fixing for your life. In S. Collins \& D. Rodrik (Eds.), Brookings trade forum: 2000. Washington, DC: Brookings Institution Press.

Calvo, G. \& Reinhart, C. (2002). Fear of Floating. Quarterly Journal of Economics, 117, 379-408.

Cavoli, T. \& Rajan, R. (2005). Have Exchange Rate Regimes in Asia Become More Flexible Post Crisis? Revisiting the Evidence. NUS Working Paper 6.

Chete, L. N. (1995). Exchange Rate Depreciation and Balance of Payments Adjustment: The Nigerian Case. NSER Individual Research Project Report, Ibadan: NISER.

Chow, H. K. \& Kim, Y. (2004). The Empirical Relationship between Exchange Rates and Interest Rates in PostCrisis Asia. Singapore Management University. Retrieved from http://www.ink.library.smu.edu.sg/soe_research/785

Clarida, R. \& Waldman, D. (2008). Is Bad News about Inflation Good News for the Exchange Rate? And If So, Can That Tell Us Anything about the Conduct of Monetary Policy? In J. Campbell (Eds.), Asset Prices and Monetary Policy(Ch.9, pp. 371-392). Chicago and London: University of Chicago Press.

Dordunoo, C. \& Njinkeu, D. (1996). Foreign Exchange Rate Regimes and Macroeconomic Performance in SubSaharan Africa. Journal of Africa Economies, 6(3), Supplement.

Eichengreen, B. (2005). Can Emerging Markets Float? Should there Inflation Target. In R. Driver, P. Sinclair, \& C, Thoenissen (Eds.), Exchange rates, capital movements and policy. London: Routledge.

Engel, C. \& West, K. D. (2006). Taylor rules and Deutsche-Mark-Dollar Real Exchange Rate. Journal of Money, Credit and Banking, 38, 1175-1194.

Ezirim, C. B., Edith, A. A. \& Muoghalu, M. I. (2012). Autoregressive Distributed Lag Analysis of Interdependencies between Inflation and Exchange Rates in Sub-Saharan Africa. The IABPAD Conference Proceedings, 9(2), 1082-1093.

Faust, J., Rogers, J., Wang, S. \& Wright, J. (2007). The High Frequency Response of Exchange Rates and Interest Rates to Macroeconomic Announcements. Journal of Monetary Economics, 54(4), 1051-1068.

Mark, N. C. (2009). Changing Monetary Policy Rules, Learning, and Real Exchange Rate Dynamics. Journal of Money, Credit and Banking, 41, 1047-1070.

Mohanty, M. \& Klau, M. (2005). Monetary Policy Rules in Emerging Market Economies: Issues and evidence. In R. Langhammer \& L. Souza (Eds.), Monetary Policy and Macroeconomic Stabilization in Latin America (pp. 205-245). Berlin Heidelberg: Springer.

Mundell, R. A. (1973a). Uncommon Arguments for Common Currencies. In H. G. Johnson \& A. K. Swoboda (Eds), The Economics of Common Currencies. London: Allen and Unwin.

Mundell, R. A.(1973b). A plan for a European Currency. In H. G. Johnson \& A. K. Swoboda (Eds), The Economics of Common Currencies. London: Allen and Unwin.

Ndung, N. S. (1999). Monetary and Exchange Rate Policy in Kenya. African Economic Research Consortium Research Paper 94.

Olagbaju, I. O. \& Akinbobola, T. O. (2016). A Non-linear Analysis of the Oil Price-Exchange Rate Nexus in Nigeria. Journal of Economics and Behavioral Studies, 8(4), 79-91.

Sanchez, M. (2005). The Link between Interest Rate and Exchange Rates: Do Contractionary Depreciations Make a Difference. European Central Bank Working Paper, 548, 1-55. Retrieved 
fromhttp://www.ecb.europa.eu/pub/pdf/scpwps/ecbwp548.pdf?3580ef9984c1f243be0de10811e5 e5ef

Semone, F. N. \& Razzak, W. A. (1999). Nominal Exchange Rates and Nominal Interest Rate Differentials. International Monetary Fund Working Paper WP/99/41, 1-41.

Vagiatzoglou, M., Christodolous, P., Pazarkis, M. \& Droglas, M. (2006). The Monetary Model of Exchange Rate Determination: In Thirty Years after the Bretton Wood. Retrieved from http: //www. Droglas.gr.

Wilson, L. \& Sheefeni, J. P. (2014).The Relationship Between Interest Rate and Exchange Rate in Namibia. Journal of Emerging Issues in Economics, Finance and Banking, 3(1), 951-961.

Yaaba, B. N., Bawa, S. \& Idrisa, A.G. (2012). The Monetary Model of Exchange Rate Determination: The case of Nigeria. Economic and Financial Review, 50(3), 125-153.

Yahya, M. H., Bany-Ariffin, A. N. \& Abdul Hadi, A. R. (2011). Revisiting the Test of Purchasing Power Parity and Structural Breaks of East Asian Countries. International Journal of Economics and Management, $5(1), 333-350$. 